\title{
ANALISIS POSTUR KERJA PEKERJA PROSES PENGEASAHAN BATU AKIK DENGAN MENGGUNAKAN METODE REBA
}

\author{
Fahmi Sulaiman ${ }^{1)}$ Yossi Purnama Sari ${ }^{2}$ \\ ${ }^{1)}$ Program Studi Teknik Industri, Politeknik LP3I Medan \\ fahmisulaiman1990@gmail.com
}

\begin{abstract}
Work Station, human Work Factor contains a high hazard potential so we need a preventive effort to prevent accidents and illness due to improper working posture. The purpose of this study was to determine the relationship postures with complaints system muscoloskletal workers agate grinding process so that the system can meminimalisirkan complaint musculoskletal workers agate grinding. To determine the posture disorders occurring in workers then used method of REBA (Rapid EntireBody Asssessment). That is the method used to analyze the workers based on the position of the body. This method is designed to evaluate the work or activities, where such work has a tendency to cause discomfort such as fatigue in the neck, spine, arm. From the observations that have been made are not ergonomic working position. It is necessary for improvement of working methods by the company.
\end{abstract}

Kata Kunci: Work Posture, Work Station, Musculoskeletal, REBA, Gems Stone.

\section{PENDAHULUAN}

Rapid Entire Body Assesment (REBA) adalah sebuah metode yang dikembangkan dalam bidang ergonomi dan dapat digunakan secara cepat untuk menilai posisi kerja pada postur leher, punggung, lengan, pergelangan tangan, dan kaki. Selain itu metode ini juga dipengaruhi faktor coupling, beban external yang dialami oleh tubuh serta aktivitas pekerja. Salah satu hal yang membedakan metode REBA dengan metode analisa lainnya adalah bahwa metode ini menganalisi seluruh bagian tubuh pekerja melalui fokus terhadap keseluruhan postur tubuh yang diharapkan bisa mengurangi potensi terjadinya musculoskletal disorders pada tubuh pekerja. Pekerjaan dengan beban yang berat mengakibatkan pengerahan tenaga yang berlebihan merupakan resiko terjadinya keluhan musculoskletal dan kelelahan dini. Postur kerja yang salah sering diakibatkan oleh letak fasilitas yang kurang sesuai dengan anthropometri sehingga mempengaruhi kinerja yang tidak alami menyebabkan ketidaknyamanan.

Berdasarkan penelitian sebelumnya yang dilakukan oleh rahma danu ternyata bahwa sikap kerja yang tidak sesuai dapat menimbulkan ketidaknyamanan pada saat bekerja. Hasil perhitungan postur kerja dengan metode REBA tentang keluhan kerja diperoleh tingkat terjadinya pada organ leher sebesar 22\%, organ tubuh bagian punggung sebesar 45\%, pada bagian kaki sebesar 37\%, pada bagian lengan atas 
sebesar 69\%, pada bagian lengan bawah sebesar 29\%, dan pada bagian pergelangan tangan sebesar $21 \%$. Selain beban pekerjaan yang cukup besar maka postur tubuh saat bekerja sangat berpengaruh dengan konsumsi energi. Analisis postur kerja dengan metode REBA pada Pekerja Proses Pengasahan Batu Akik sangat perlu dilakukan untuk mengantisipasi hal-hal yang tidak diinginkan, permasalahan yang dihadapi seorang pekerja proses pengasahan batu akik adalah pekerja kurang memperhatikan keselamatan dan resiko yang terjadi bila pekerja terus menerapkan posisi kerja yang tidak sesuai dengan anthropometri. untuk itu penulis ingin menganalisa penilaian postur kerja berdasarkan metode REBA pada pekerja proses pengasahan batu akik dengan metode kerja dan proses kerja. Adapun Rumusan permasalahan adalah bagaimana penilaian postur kerja berdasarkan metode REBA pada pekerja proses pengasahan batu akik

\section{KAJIAN PUSTAKA}

\subsection{Pengertian Ergonomi}

Istilah "ergonomi" berasal dari bahasa latin yaitu ERGON (KERJA) dan NOMOS (HUKUM ALAM) dan dapat didefinisikan sebagai studi tentang aspek aspek manusia dalam lingkungan yang ditinjau secara anatomi, fisiologi, psikologi, engineering, manajemen dan desain atau perancangan (Nurmianto, 2008). Menurut Sutalaksana (1979), egonomi adalah suatu cabang ilmu yang Sistematis untuk memanfaatkan informasi-informasi mengenai sifat, kemampuan dan keterbatasan manusia untuk merancang suatusistem kerja sehingga orang dapat hidup dan bekerjapa dasistem itu dengan baik, yaitu mencapai tujuan yang diinginkan melalui pekerjaan itu dengan efektif, aman, dan nyaman.

\subsection{Tujuan, Manfaat, dan Ruang Lingkup Ergonomi}

Adapun tujuan penerapan ergonomic adalah sebagai berikut: 1)Meningkatkan kesejahteraan fisik dan mental, dengan meniadakan beban kerja tambahan (fisikdan mental), mencegah penyakit akibat kerja, dan meningkatkan kepuasan kerja. 2) Meningkat kan kesejahteraan social dengan jalan meningkatkan kualitas kontak sesama pekerja, pengorganisasian yang lebih baik dan menghidupkan system kebersamaan dalam tempat kerja. 3) Berkontribusi di dalam keseimbangan rasional antara aspek-aspek teknik, ekonomi, antropologi dan budaya dari sistem manusia-mesin untuk tujuan meningkatkan efisiensi sistemmanusia-mesin. 
Manfaat pelaksanaan ergonomic adalah sebagai berikut: 1) Menurunnya angka kesakitan akibat kerja. 2) Menurunnya kecelakaan kerja. 3) Biaya pengobatan dan kompensasi berkurang. 4) Stress akibat kerja berkurang. 5) Produktivitas membaik. 7) Alur kerja bertambah baik. 8) Rasa aman karena bebasdari gangguan cedera. 9) Kepuasan kerja meningkat.

Ruang lingkup ergonomic sangat luas aspeknya, antara lain meliputi: 1) Teknik. 2) Fisik. 3) Pengalaman psikis Anatomi, utamanya yang berhubungan dengan kekuatan dan gerakan otot dan persendian. 1)Anthropometri. 2)Sosiologi. 3)Fisiologi, terutama berhubungan dengan temperature tubuh, Oxygen up take, pols, danaktivitasotot. 4) Desain.

\subsection{Pengertian Postur Kerja}

Postur kerja merupakan titik penentu dalam menganalisa keefektifan dari suatu pekerjaan. Apabila postur kerja yang dilakukan oleh operator sudah baik dan ergonomis maka dapat dipastikanhasil yang diperoleholeh operator tersebut akan baik. Akan tetapi bila postur kerja operator tersebut tidak ergonomis maka operator tersebut akan mudah kelelahan. Apabila operator mudah mengalami kelelahan maka hasil pekerjaan yang dilakukan operator tersebut jugaakan mengalami penurunan dan tidak sesuai dengan yang diharapkan (Susihono, 2012).

\subsection{Pengaruh Postur Kerja Terhadap Musculos Keletal}

Musculos keletal adalah risiko kerja mengenai gangguan otot yang disebabkan oleh kesalahan posturkerja dalam melakukan suatu aktivitas kerja. Keluhan musculoskeletal adalah keluhan pada bagian-bagianotot skeletal yang dirasakan oleh seseorang mulai dari keluhan sangat ringan sampai sangat sakit. Apabila otot menerima beban statis secara berulang dan dalam waktu yang lama, akan dapat menyebabkan keluhan berupa kerusakan padasendi, ligament dan tendon. Keluhan hingga kerusakan inilah yang biasanya diistilahkan dengan keluhan musculoskeletal disorders (MSDs) atau cedera pada system muskuloskeletal. Secara garis besar keluhan otot dapat dikelompokkan menjadi dua, yaitu (Tarwaka, 2010): 1)Keluhan sementara (reversible), yaitu keluhan otot yang terjadi pada saat otot menerima beban statis, namun demikian keluhan tersebut akan namun demikian keluhan tersebut akan segera hilang apabila pembebanan dihentikan. 2) Keluhan menetap (persistent), yaitu keluhan otot yang 
bersifat menetap. Walaupun pembebanan kerja telah dihentikan, namun rasa sakit pada otot masih terus berlanjut.

\subsection{Faktor-Faktor Yang Mempengaruhi Postur Kerja}

Postur adalah posisi relatif bagian tubuh tertentu padasaat bekerja yang ditentukan oleh ukuran tubuh, desain area kerjadan task requirements serta ukuran peralatan/benda lainnya yang digunakan saat bekerja. Postur dan pergerakan memegang peranan penting dalam ergonomi. Salah satu penyebab utama gangguan otot rangka adalah posturjanggal (awkward posture).

\subsection{Risiko Postur Tubuh Yang Salah}

Postur janggal dapat menyebabkan terjadinya kelelahan dan ketidaknyamanan. Dilakukannya postur janggal pada jangka waktu panjang dapat menyebabkan cidera dan keluhan pada jaringan otot rangka maupun saraf tepi.

\subsection{Rapid Entire Body Assessment (Reba)}

Rapid Entire Body Assessment adalah sebuah metode yang dikembangkan dalam bidang ergonomi dan dapat digunakan secara cepat untuk menilai posisi kerja atau postur leher, punggung, lengan pergelangan tangan dan kaki seorang operator. Selain itu metode ini juga dipengaruhi faktor coupling, beban eksternal yang ditopang oleh tubuh serta aktifitas pekerja. Penilaian dengan menggunakan. REBA tidak membutuhkan waktu yang lama untuk melengkapi dan melakukan scoring general pada daftar aktivitas yang mengindikasikan perlu adanya pengurangan resiko yang diakibatkan postur kerja operator (Hignett dan Mc Atamney, 2000). Metode ergonomi tersebut mengevaluasi postur, kekuatan, aktivitas dan factor coupling yang menimbulkan cidera akibat aktivitas yang berulang-ulang. Penilaian postur kerja dengan metode ini dengan cara pemberian skor resiko antara satu sampai lima belas, yang mana skor tertinggi menandakan level yang mengakibatkan resiko yang besar (bahaya) untuk dilakukan dalam bekerja. Hal ini berarti bahwa skor terendah akan menjamin pekerjaan yang diteliti bebas dari ergonomic hazard. REBA dikembangkan untuk mendeteksi postur kerja yang beresiko dan melakukan perbaikan sesegera mungkin. REBA dikembangkan tanpa membutuhkan piranti khusus. Ini memudahkan peneliti untuk dapat dilatih dalam melakukanpemeriksaan dan pengukuran tanpa. biaya peralatan tambahan. Pemeriksaan REBA dapat dilakukan di tempat yang terbatas tanpa menggangu pekerja. 
Berikut ini adalah Range dan score Pergerakan Tubuh berdasarkan metode REBA.

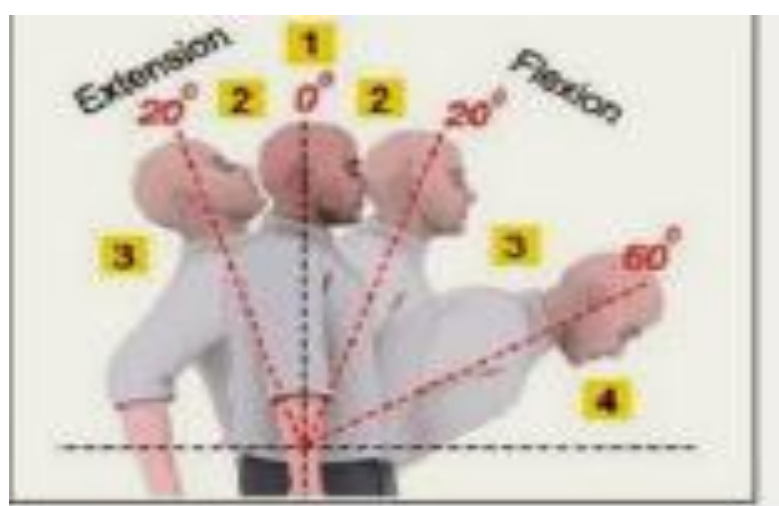

Gambar 1. Range Pergerakan Punggung (+1 Jika Punggung Memutar/Miring Ke Samping)

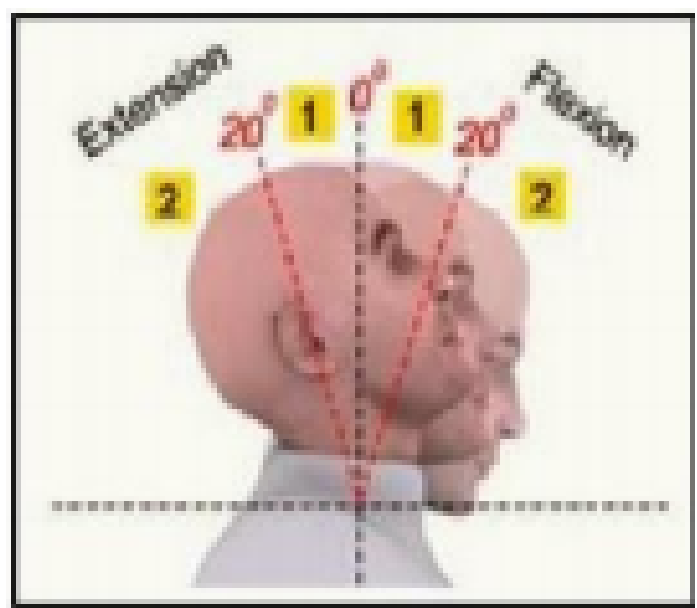

Gambar 2. Range Leher (+1 Jika Leher Memutar/Miring Ke Samping)

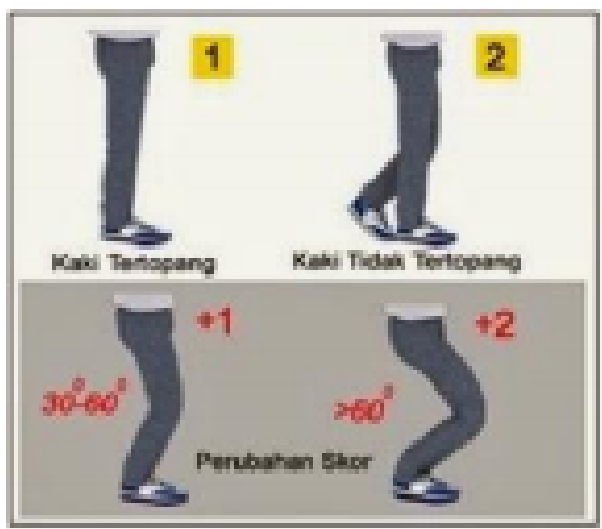

Gambar 3. Range Pergerakan Kaki i +1 Jika Lutut Antara $30^{\circ}$ Dan $60^{\circ}$ Flexion +2 Jika Lutut $>60^{\circ}$ Flexion) 


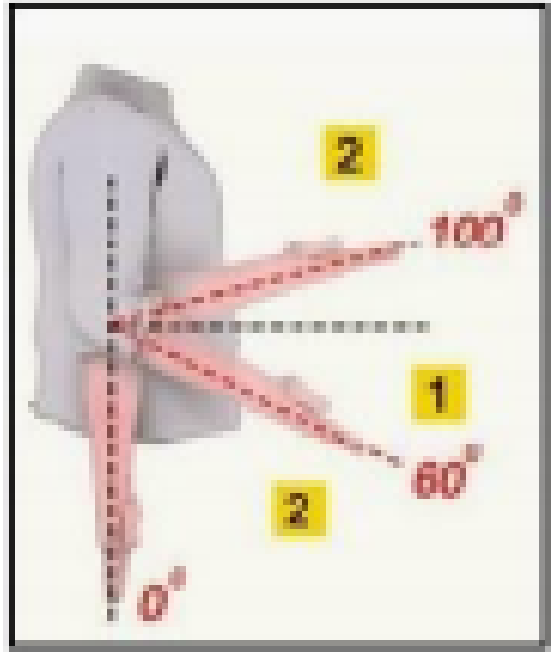

Gambar 4. Range Pergerakan Lengan Atas(+1 Jika Posisi Lengan Atas Adducted And Rotated. +1 Jika Bahu Ditinggikan, +1 Jika Bersandar, Bobot Lengan Ditiopang Atau Sesuai Gravitasi)

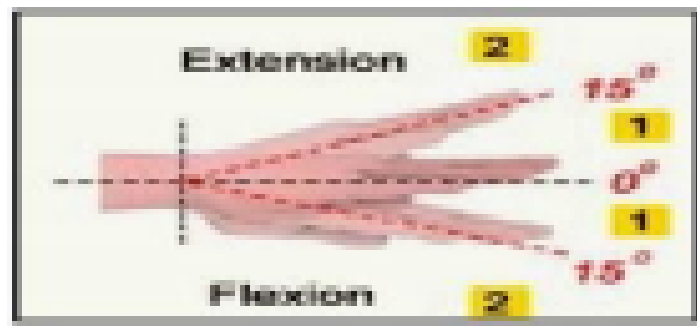

Gambar 5. Range Pergerakan Lengan Atas (+1 Jika pergelangan tangan memutar)

Tabel 1. Tabel Resiko Ergonomi

\begin{tabular}{ccc}
\hline REBA Skor & Risk Level & Tindakan \\
\hline 1 & Diabaikan & Tidak diperlukan \\
$2-3$ & Low & Mungkin Diperlukan \\
$4-7$ & Medium & Diperlukan \\
$8-10$ & High & Segera diperluka \\
$11-15$ & Veri High & Diperlukan Sekarang \\
\hline
\end{tabular}

\section{METODOLOGI}

\subsection{Objek Penelitian}

Penelitian ini dilakukan di UKM pengasahan batu akik dengan tahapan dokumentasi, wawancara dan data postur kerja. Dokumentasi dilakukan dengan tujuan untuk mengananlisis postur kerja. 


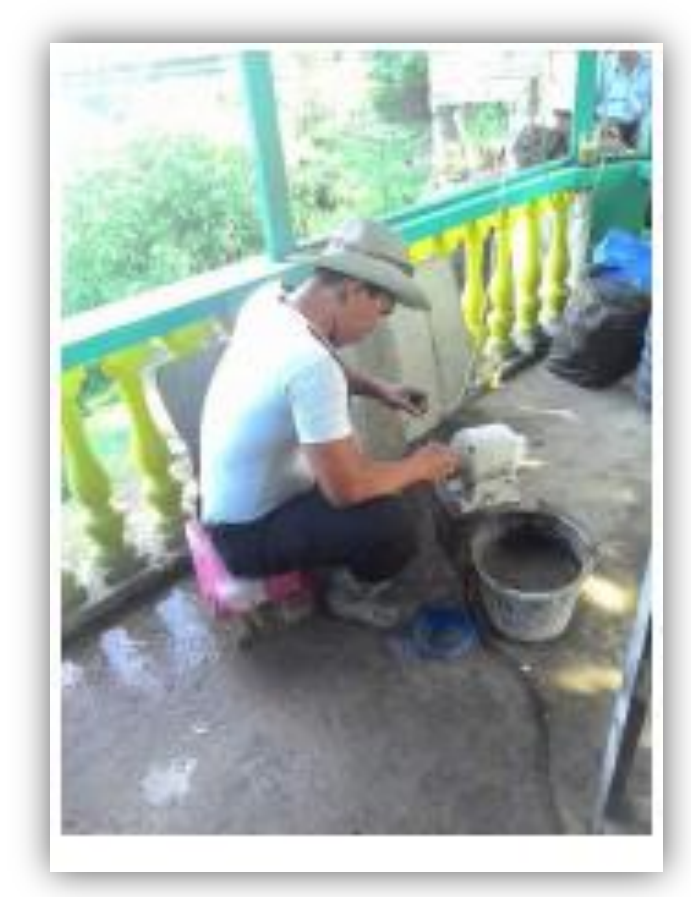

\section{Gambar 6. Pengasah Batu Akik}

\section{HASIL DAN DISKUSI}

Pencatatan dan pengumpulan data mengenai postur kerja tiap kegiatan menggunakan foto pada pekerjapengasahan batu akik dilakukan pada hari kamis tanggal 19 Maret 2015. Untuk menentukan sudut-sudut pada postur tubuh sikap kerja yang dilakukan oleh pekerjapengasahan batu akik meliputi foto postur kerja

Berikut ini foto atau gambar postur kerja saat melakukan aktivitas kerja dapat dilihat pada gambar 8 Sebagai berikut :

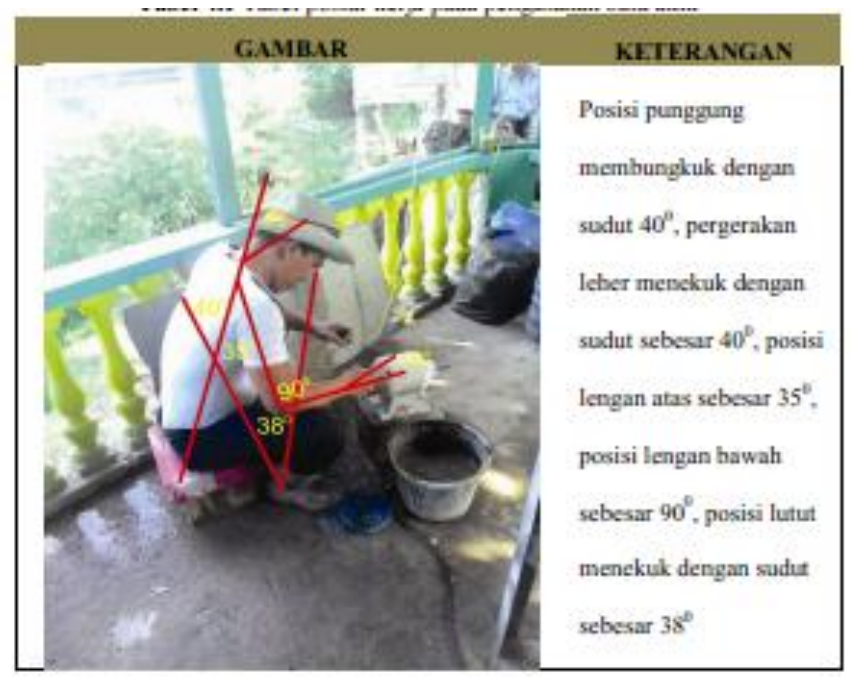

Gambar 7. Posisi Kerja

Untuk Bagia A, yang terdiri atas bagian Punggung, Leher dan kaki adalah sebagai berikut: 
1. Punggung

Dari gambar di atas dapat diketahui bahwa pergerakan punggung termasuk dalam posisi membungkuk dengan sudut $40^{\circ}$ (Skor REBA untuk pergerakan punggung adalah $3+1$ jika memutar atau miring kesamping $=4$ )

\begin{tabular}{|c|c|c|}
\hline Pergerakan & Score & \multirow[t]{4}{*}{ Perubahan Score } \\
\hline Tegal/ alumiah & 1 & \\
\hline $0^{10}-20^{0}$ flexian & & \\
\hline $0^{0}-20^{0}$ extersion & 2 & \\
\hline $\begin{array}{l}20^{4}-60^{4} \text { flexion } \\
>20^{3} \text { extension }\end{array}$ & 3 & \\
\hline $560^{0}$ flexian & 4 & \\
\hline
\end{tabular}

Gambar 8. Skor Pergerakan Punggung

2. Leher

Dari gambar 4.1 dapat diketahui bahwa pergerakan leher dengan sudut sebesar $40^{0}$ terhadap sumbuh tubuh. (Skor REBA untuk pergerakan leher adalah 2)

\begin{tabular}{|c|c|c|}
\hline Pergerakan & Score & Perubahan Score \\
\hline $0^{\prime \prime}-20^{\prime \prime}$ flecian & 1 & \multirow{2}{*}{$\begin{array}{l}\text { +1 Jika memutar } \\
\quad \text { Atau } \\
\text { miring ke samping }\end{array}$} \\
\hline $\begin{array}{l}20^{\prime \prime} \text { ferion atau } \\
\text { Extersion } \\
\end{array}$ & 2 & \\
\hline
\end{tabular}

Gambar 9. Skor Pergerakan Leher

3. Kaki (Legs)

Dari gambar 4.1 dapat diketahui bahwa posisi duduk, dan lutut menekuk dengan sudut sebesar $38^{\circ}$ (Skor REBA untuk pergerakan kaki adalah $1+1$ kaki tertopang $=2$ )

\begin{tabular}{|c|c|c|}
\hline \multicolumn{1}{c|}{ Pergerakan } & Seore & $\begin{array}{c}\text { Perubahan Seore } \\
+1 \text { Jika lutut antara } 30^{\circ} \\
\text { dan } 60^{\circ} \text { flerion }\end{array}$ \\
$\begin{array}{l}\text { Kaki tertopung, bobot } \\
\text { tersebar merata, jalan } \\
\text { atau duduk }\end{array}$ & 1 & $\begin{array}{l}+2 \text { Jika lutut }>60^{\circ} \\
\text { flexion (tidak ketika } \\
\text { duduk) }\end{array}$ \\
\hline $\begin{array}{l}\text { Kaki tidak tertopang } \\
\text { bobot tidak tersebar } \\
\text { merata / postur tidak } \\
\text { stabil }\end{array}$ & 2 & \\
\hline
\end{tabular}

\section{Gambar 10. Skor Pergerakan Kaki}

Adapun Skor REBA untuk Tabel A adalah sebagai berikut: 


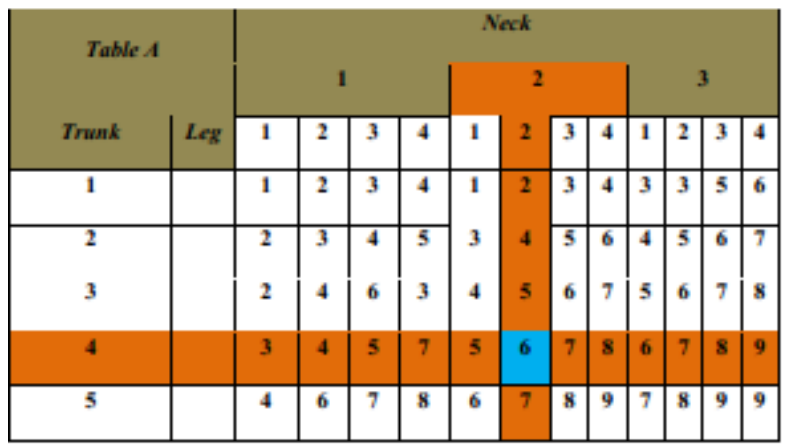

Gambar 11. Tabel Skor REBA A

Untuk bagian B pada Skor REBA terdiri atas Lengan atas, lengan bawah dan pergelangan tangan.

1. Lengan Atas

Dari gambar 4.1 dapat diketahui bahwa sudut pergerakan lengan atas ke depan sebesar $35^{\circ}$ terhadap sumbu tubuh.

(Skor REBA untuk pergerakan lengan atas adalah $2+1$ posisi lengan abducted $=3$ )

\begin{tabular}{|c|c|c|}
\hline Pergerakan & Score & Perubahan Score \\
\hline $\begin{array}{l}20^{\prime} \text { extension sampai } 20^{\prime} \\
\text { flexion }\end{array}$ & 1 & +1 Jika posisi lengan : \\
\hline $20^{\prime 2}$ extension & 2 & $\begin{array}{l}\text { - Abduted } \\
\text { - Rotated }\end{array}$ \\
\hline $45^{11}-90^{1}$ flexion & 3 & +1 jika bahu ditinggikan \\
\hline S90"flexian & 4 & $\begin{array}{l}\text {-1 Jika bersandar, bobot } \\
\text { lengan ditopang atau sesuai } \\
\text { Gravitasi }\end{array}$ \\
\hline
\end{tabular}

Gambar 12. Skor Pergerakan Lengan Atas

1. Lengan bawah (Lower arm)

Dari gambar 4.1 dapat diketahui bawah sudut pergerakan lengan bawahmembentuk sudut $90^{\circ}$ (Skor REBA untuk pergerakan lengan bawah adalah 1)

\begin{tabular}{|c|c|}
\hline Pergerakan & Score \\
\hline $60^{\prime \prime}-100^{\prime \prime}$ flexion & I \\
\hline $460^{1}$ flexion $3100^{1}$ flexion & 2 \\
\hline
\end{tabular}

Gambar 13. Skor Pergerakan Lengan Bawah 
2. Pergelangan Tangan

Dari gambar 4.1 dapat diketahui bahwa sudut pergerakan pergelangan tangan kedepan (Flexion)terhadap lengan bawah termasuk dalam range pergerakan $18^{0}$ flexion. (Skor REBA untuk pergerakan pergelangan tangan adalah 2)

\begin{tabular}{|c|c|c|}
\hline Pergerakan & Soure & Perubahun soore \\
\hline 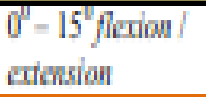 & $\rrbracket$ & \multirow{2}{*}{$\begin{array}{l}+1 \text { Jika pergelangan tangun } \\
\text { menyimpang atau berpurar }\end{array}$} \\
\hline $\begin{array}{l}\text { 35 flowan/ } \\
\text { ctwarian }\end{array}$ & 2 & \\
\hline
\end{tabular}

\section{Gambar 14. Skor Pergerakan Pergelangan Tangan}

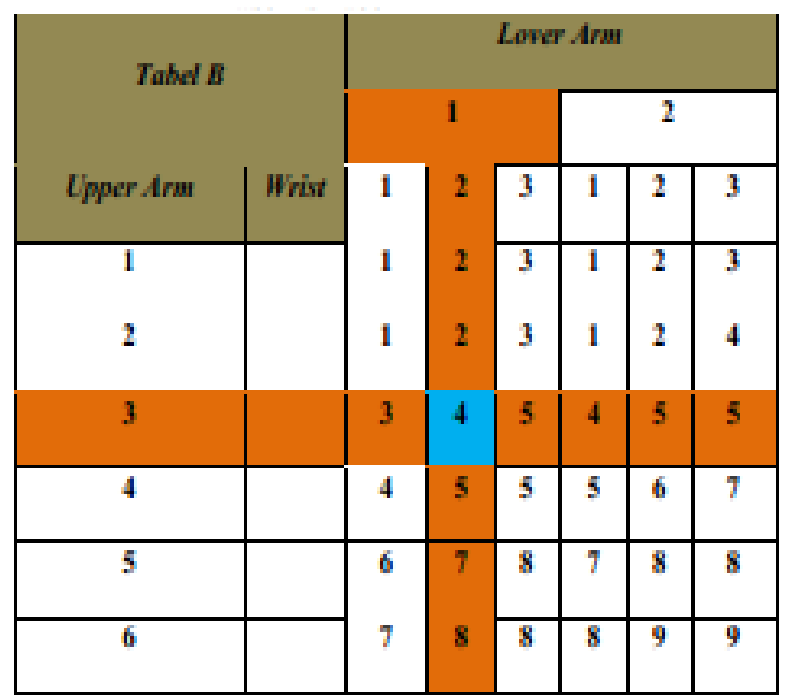

Gambar 15. Tabel Skor REBA B

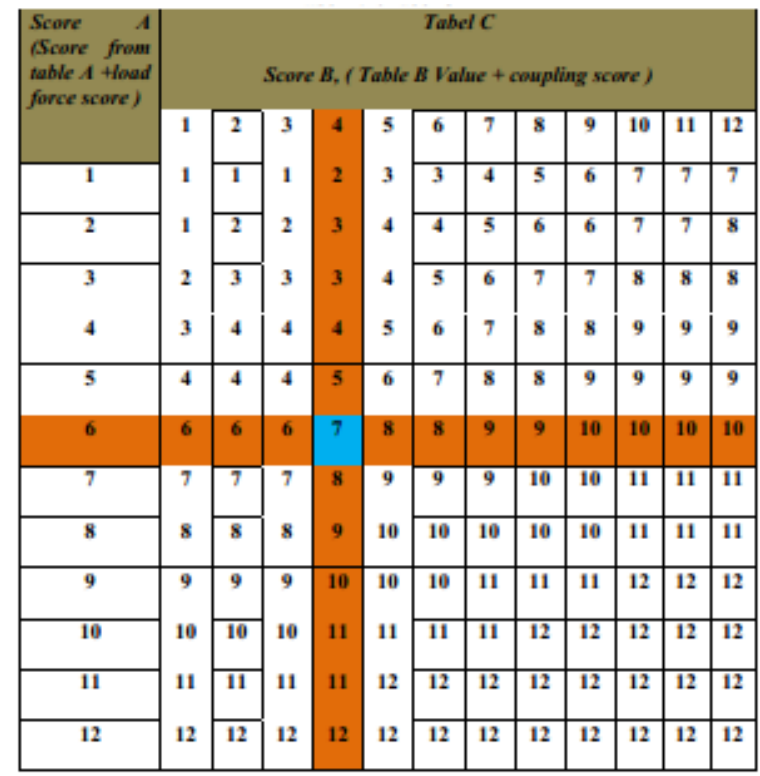

Gambar 16. Tabel Skor REBA C 
Untuk berat beban dan Coupling adalah 0

Berdasarkan perhitungan Tabel REBA maka didapatlah bahwa skor postur tubuh berdasarkan metode REBA adalah 3 dengan level tindakan tinggi dan perlu segera diperbaiki.

\section{KESIMPULAN}

Berdasarkan pembahasan yang telah dilakukan, maka dapat di ambil kesimpulan adalah sebagai berikut: Sebelum perbaikan postur kerja telah menghasilkan postur kerja level 3 dengan tingkatan resiko pada level ini tinggi. Maka sangat perlu dilakukan perbaikan postur kerja untuk mengurangi resiko kerja. Perhitungan Reba akan diperkuat untuk mengetahui posisi kerja yang termasuk dalam katagori kerja berat dan sangat perlu berbaikan. dari hasil analisis perhitungan REBA maka perlu usulan perbaikan sikap kerja pada pekerja pengasahan batu akik. Hal tersebut perlu dilakukan agar memberikan perbaikan ergonomis bagi postur kerja pekerja proses pengasahan batu akik

\section{DAFTAR PUSTAKA}

Bridger. 1995. introductiaon to ergonomics. Singapore:McGraw-Hill

Humantech. 1995.Humantechapplied ergonomics Training Manual, $2^{\text {nd }}$.ed.,Berkelery Vale, Australia, Cetakan 1. Surakarta : UNIBA Prees. (Online.)

Merulalia (2010) Posturtubuh yang ergonomis saat bekerja. Skripsi Fakultas Kesehatan Masyarakat USU. Medan.www.K3(OHAS)ac.id

Miftahudin. 2011.Analisisposturkerja di CV. Cahyo Nugroho Jati Sukoharjo

Nurmianto, Eko. 1996. Ergonomi: Konsep Dasar dan Aplikasinya. Surabaya: Guna Widya.

Pheasant stephen. 1986. Bodypace: anthropometry, ergonomics, end design London: taylor \& francis

Pulat, B. Mustafa 1992. Fundamentals of Industrial Ergonomics. New Jersey: Prentice Hall International

Sue Hignett and Lynn McAtamney. 2000. Rapid Upper Limb Assessment (RULA); Applied Ergonomics 